\title{
Ozone air quality and radiative forcing consequences of changes in ozone precursor emissions
}

\author{
J. Jason West, ${ }^{1,2,3}$ Arlene M. Fiore, ${ }^{4}$ Vaishali Naik, ${ }^{2}$ Larry W. Horowitz, ${ }^{4}$ \\ M. Daniel Schwarzkopf, ${ }^{4}$ and Denise L. Mauzerall ${ }^{2,5}$ \\ Received 21 December 2006; revised 8 February 2007; accepted 22 February 2007; published 27 March 2007.
}

[1] Changes in emissions of ozone $\left(\mathrm{O}_{3}\right)$ precursors affect both air quality and climate. We first examine the sensitivity of surface $\mathrm{O}_{3}$ concentrations $\left(\mathrm{O}_{3}^{\text {srf }}\right)$ and net radiative forcing of climate $\left(\mathrm{RF}_{\text {net }}\right)$ to reductions in emissions of four precursors - nitrogen oxides $\left(\mathrm{NO}_{x}\right)$, non-methane volatile organic compounds, carbon monoxide, and methane $\left(\mathrm{CH}_{4}\right)$. We show that long-term $\mathrm{CH}_{4}$-induced changes in $\mathrm{O}_{3}$, known to be important for climate, are also relevant for air quality; for example, $\mathrm{NO}_{x}$ reductions increase $\mathrm{CH}_{4}$, causing a long-term $\mathrm{O}_{3}$ increase that partially counteracts the direct $\mathrm{O}_{3}$ decrease. Second, we assess the radiative forcing resulting from actions to improve $\mathrm{O}_{3}$ air quality by calculating the ratio of $\Delta \mathrm{RF}_{\text {net }}$ to changes in metrics of $\mathrm{O}_{3}^{\text {srf. }}$. Decreases in $\mathrm{CH}_{4}$ emissions cause the greatest $\mathrm{RF}_{\text {net }}$ decrease per unit reduction in $\mathrm{O}_{3}^{\text {srf }}$, while $\mathrm{NO}_{x}$ reductions increase $\mathrm{RF}_{\text {net. }}$. Of the available means to improve $\mathrm{O}_{3}$ air quality, therefore, $\mathrm{CH}_{4}$ abatement best reduces climate forcing. Citation: West, J. J., A. M. Fiore, V. Naik, L. W. Horowitz, M. D. Schwarzkopf, and D. L. Mauzerall (2007), Ozone air quality and radiative forcing consequences of changes in ozone precursor emissions, Geophys. Res. Lett., 34, L06806, doi:10.1029/2006GL029173.

\section{Introduction}

[2] Concentrations of ozone $\left(\mathrm{O}_{3}\right)$ have increased historically at the surface in industrialized regions, and in the global background troposphere [Vingarzan, 2004]. Actions to decrease tropospheric $\mathrm{O}_{3}$ to improve air quality have emphasized reducing emissions of short-lived $\mathrm{O}_{3}$ precursors - nitrogen oxides $\left(\mathrm{NO}_{x}\right)$, non-methane volatile organic compounds (NMVOCs), and carbon monoxide (CO) - on urban and regional scales. Methane $\left(\mathrm{CH}_{4}\right)$, a long-lived $\mathrm{O}_{3}$ precursor (lifetime $\sim 9 \mathrm{yr}$ ), contributes to the global background concentration of tropospheric $\mathrm{O}_{3}$, and $\mathrm{CH}_{4}$ emission controls have received recent attention as a means of international $\mathrm{O}_{3}$ air quality management [Fiore et al., 2002; Dentener et al., 2005; West and Fiore, 2005; West et al., 2006].

\footnotetext{
${ }^{1}$ Atmospheric and Oceanic Sciences Program, Princeton University, Princeton, New Jersey, USA.

${ }^{2}$ Woodrow Wilson School of Public and International Affairs, Princeton University, Princeton, New Jersey, USA.

${ }^{3}$ University of North Carolina at Chapel Hill, Chapel Hill, North Carolina, USA.

${ }^{4}$ NOAA Geophysical Fluid Dynamics Laboratory, Princeton, New Jersey, USA.

${ }^{5}$ Department of Geosciences, Princeton University, Princeton, New Jersey, USA.
}

Copyright 2007 by the American Geophysical Union. 0094-8276/07/2006GL029173
[3] Reducing emissions of any precursor to improve $\mathrm{O}_{3}$ air quality also influences climate, as such changes affect the concentrations of and radiative forcing from both $\mathrm{O}_{3}$ and $\mathrm{CH}_{4}$. Reductions in surface $\mathrm{NO}_{x}$ emissions, for example, decrease $\mathrm{O}_{3}$ and global concentrations of the hydroxyl radical $(\mathrm{OH})$. Since reaction with $\mathrm{OH}$ is the major sink for $\mathrm{CH}_{4}, \mathrm{NO}_{x}$ reductions increase the atmospheric lifetime and concentrations of $\mathrm{CH}_{4}$. The resulting positive radiative forcing from increased $\mathrm{CH}_{4}$ roughly cancels, or slightly exceeds, the negative forcing from decreased $\mathrm{O}_{3}$ globally [Fuglestvedt et al., 1999; Wild et al., 2001; Fiore et al., 2002; Berntsen et al., 2005; Naik et al., 2005; Shindell et al., 2005]. In contrast, reductions in emissions of NMVOCs, $\mathrm{CO}$, and $\mathrm{CH}_{4}$ increase $\mathrm{OH}$ and decrease the forcing from both $\mathrm{O}_{3}$ and $\mathrm{CH}_{4}$ [Prather et al., 2001; Fiore et al., 2002].

[4] These changes in $\mathrm{CH}_{4}$ will also affect $\mathrm{O}_{3}$ on the longer time scale of the $\mathrm{CH}_{4}$ perturbation lifetime. In the case of $\mathrm{NO}_{x}$ controls, the $\mathrm{CH}_{4}$ increase induces a long-term $\mathrm{O}_{3}$ increase, which partially counteracts the short-term $\mathrm{O}_{3}$ decrease. Conversely, controls on NMVOCs and CO cause a long-term $\mathrm{O}_{3}$ decrease in addition to the short-term $\mathrm{O}_{3}$ decrease. These long-term changes in $\mathrm{O}_{3}$ have been included in estimates of net radiative forcing [Wild et al., 2001; Berntsen et al., 2005; Naik et al., 2005]; here we also quantify their relevance for long-term surface $\mathrm{O}_{3}$ air quality.

[5] Local actions to improve $\mathrm{O}_{3}$ air quality therefore affect surface $\mathrm{O}_{3}$ and radiative forcing on global scales; while the global effects of emission changes in a single airshed are expected to be small, the cumulative effects of such actions in many polluted regions are analyzed here. The first objective of this study is to simulate the sensitivity of surface $\mathrm{O}_{3}$ concentrations, and of the net radiative forcing due to $\mathrm{O}_{3}$ and $\mathrm{CH}_{4}$, to global emission reductions of $\mathrm{NO}_{x}$, NMVOCs, $\mathrm{CO}$, and $\mathrm{CH}_{4}$, using consistent methods. In doing so, we account for the long-term changes in $\mathrm{O}_{3}$ via $\mathrm{CH}_{4}$. These estimates can be used together with information on the costs and feasibility of reducing precursor emissions, in the integrated planning of actions to address $\mathrm{O}_{3}$ air quality and climate change. Changes in aerosol radiative forcing are not included in our estimate of net radiative forcing, but are estimated here to be small (section 3.1.). The second objective addresses the effects of actions to improve surface $\mathrm{O}_{3}$ air quality on radiative forcing. Because precursor emissions are being reduced in many nations to improve $\mathrm{O}_{3}$ air quality, and because such actions affect climate, we compare the radiative forcing consequences of decreasing surface $\mathrm{O}_{3}$ through reductions in emissions of each precursor. We normalize the change in net radiative forcing by changes in surface $\mathrm{O}_{3}$ concentration metrics, and 

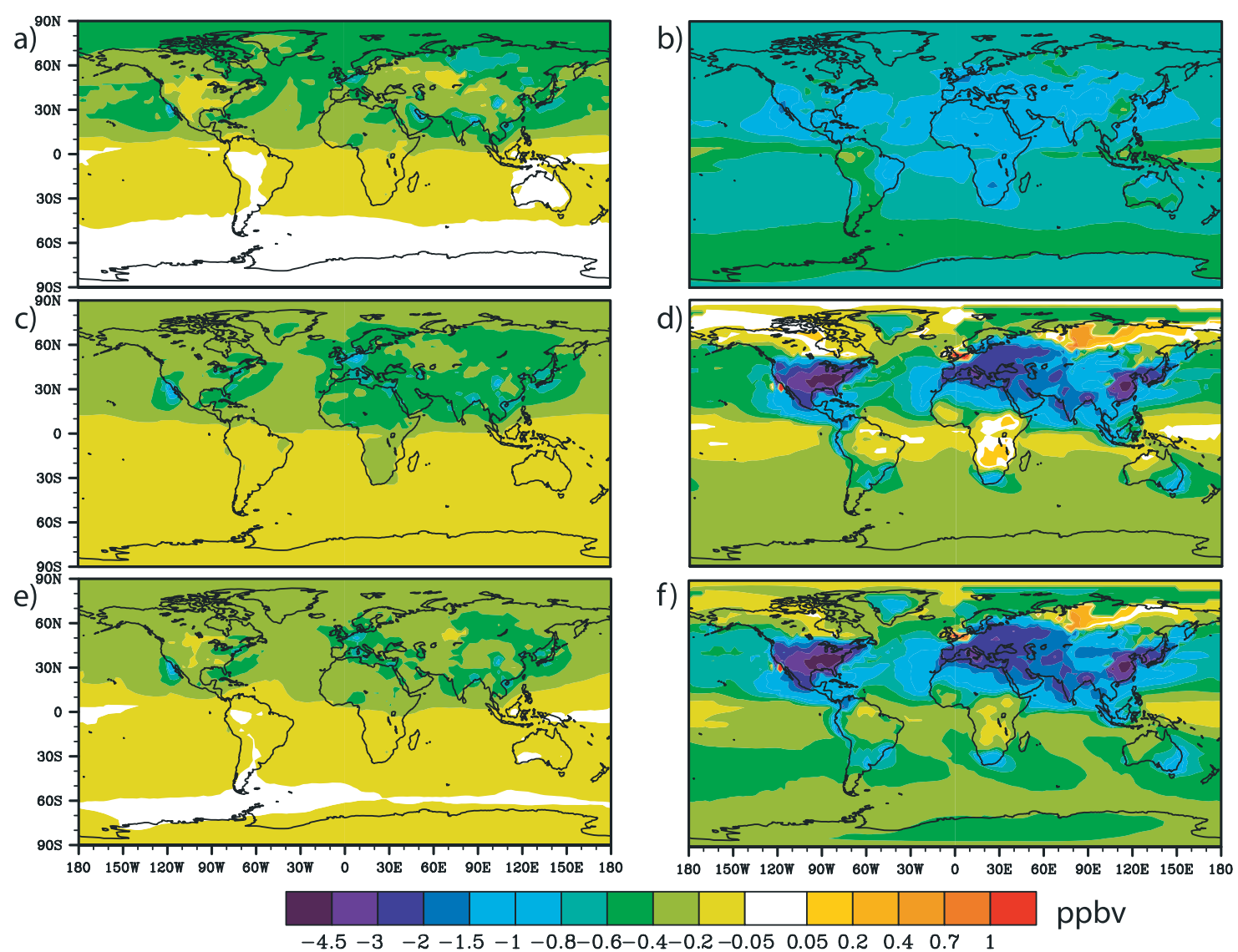

Figure 1. The change in 8-hr. daily maximum surface $\mathrm{O}_{3}$ concentrations, averaged over the "O $\mathrm{O}_{3}$ season" (the three-month period with highest $\mathrm{O}_{3}$ in each grid cell), due to $20 \%$ reductions in global anthropogenic emissions of $\mathrm{O}_{3}$ precursors. Results are shown at steady state for (a) NMVOCs, (b) $\mathrm{CH}_{4}$, (c) $\mathrm{CO}$, and (d) $\mathrm{NO}_{x}$, and short-term responses are shown for (e) $\mathrm{CO}$ and (f) $\mathrm{NO}_{x}$. The short-term response for NMVOCs is nearly identical to the steady-state response.

present this ratio as an indicator of the climate forcing resulting per unit improvement in $\mathrm{O}_{3}$ air quality.

\section{Methods}

[6] We use the MOZART-2 global three-dimensional model of tropospheric chemistry and transport, driven with meteorology from the middle atmosphere version of the Community Climate Model (MACCM3), with a horizontal resolution of about $2.8^{\circ}$ by $2.8^{\circ}$ and 34 vertical levels. Emissions in the base simulation are representative of the early 1990s. The base simulation includes only minor model updates from previous model versions [Horowitz et al., 2003; Naik et al., 2005] that have been thoroughly evaluated with measurements [Horowitz et al., 2003].

[7] We simulate the effects of sustained uniform $20 \%$ reductions in global anthropogenic emissions of four precursors individually $\left(\mathrm{NO}_{x}, \mathrm{NMVOCs}, \mathrm{CO}\right.$, and $\left.\mathrm{CH}_{4}\right)$, relative to the base simulation. The anthropogenic sources reduced in these experiments include the combustion of biofuels (among other sources), but exclude other forms of biomass burning. Changes in emissions of each gas-phase precursor are assumed to occur independently; we neglect possible changes in emissions of co-emitted species due to the control action. A fixed global $\mathrm{CH}_{4}$ mixing ratio of 1700 ppbv is used in the base and $\mathrm{NO}_{x}, \mathrm{NMVOC}$, and $\mathrm{CO}$ control simulations. In the $\mathrm{CH}_{4}$ control case, we decrease the $\mathrm{CH}_{4}$ mixing ratio to $1460 \mathrm{ppbv}$, the steady-state mixing ratio that would result from a $20 \%$ anthropogenic emission reduction, based on the $\mathrm{CH}_{4}-\mathrm{OH}$ feedback factor of 1.33 derived from the model (see auxiliary material). ${ }^{1}$ All simulations are conducted for 25 months, with results presented for the final 12 months.

[8] The short-term $\mathrm{O}_{3}$ response to changes in $\mathrm{NO}_{x}$, NMVOC, and CO is simulated directly in the model, and is assumed constant into the future. This short-term $\mathrm{O}_{3}$ change adds to the long-term change via $\mathrm{CH}_{4}$ (the "primary mode" [Prather, 1996]) to give the net $\mathrm{O}_{3}$ change at steady state [Wild et al., 2001]. Previous studies have typically focused only on the short-term $\mathrm{O}_{3}$ effects of $\mathrm{NO}_{x}$, NMVOC and CO reductions [Fuglestvedt et al., 1999; Fiore et al., 2002], or used other model results to estimate the long-term response [Berntsen et al., 2005; Naik et al., 2005]. We estimate the long-term $\mathrm{O}_{3}$ response by scaling the hourly $\mathrm{O}_{3}$ change in each model grid cell from our $\mathrm{CH}_{4}$ emission reduction simulation to the implied $\mathrm{CH}_{4}$ changes derived from the other precursor reduction simulations (based on the simulated change in $\mathrm{CH}_{4}$ lifetime and the $\mathrm{CH}_{4}-\mathrm{OH}$ feedback factor; see equations in auxiliary material). Adding the estimated long-term change in $\mathrm{O}_{3}$ to the simulated short-

${ }^{1}$ Auxiliary material data sets are available at ftp://ftp.agu.org/apend/gl/ 2006gl029173. Other auxiliary material files are in the HTML. 


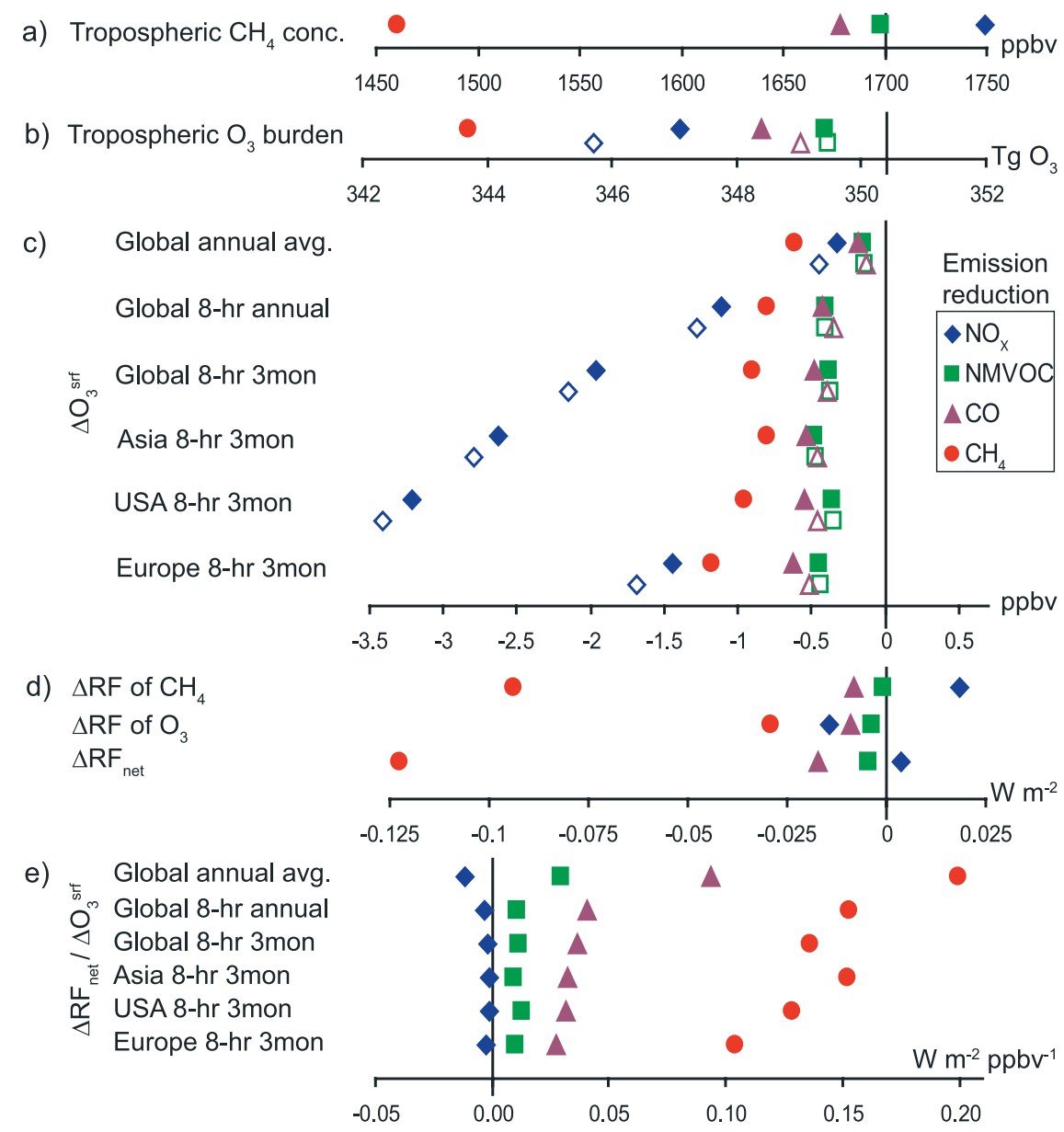

Figure 2. Effects of sustained $20 \%$ reductions in global anthropogenic emissions of four $\mathrm{O}_{3}$ precursors on metrics of (a) $\mathrm{CH}_{4}$ concentration, (b) $\mathrm{O}_{3}$ burden, (c) surface $\mathrm{O}_{3}$ concentration, (d) radiative forcing (RF), and (e) $\Delta \mathrm{RF}_{\text {net }} / \Delta \mathrm{O}_{3}^{\text {srf }}$. Steady-state results are shown with solid symbols; open symbols indicate short-term results (the $\mathrm{CH}_{4}$ perturbation only causes a steady-state change). Base simulation values are shown by the vertical lines (see auxiliary material). Air quality $\Delta \mathrm{O}_{3}^{\text {srf }}$ metrics include the population-weighted 8-hr. $\mathrm{O}_{3}$, annually averaged globally and averaged over the three-month $\mathrm{O}_{3}$ season globally and regionally (all 8-hr. metrics shown are population-weighted). Radiative forcing indicates the global annual mean forcing at the tropopause.

term change, and assuming $\mathrm{O}_{3}$ scales linearly with $\mathrm{CH}_{4}$, is supported by previous model results [Fiore et al., 2002; Shindell et al., 2005].

[9] Long-term $\mathrm{O}_{3}$ changes will gradually approach their final response according to the modeled perturbation lifetime of $\mathrm{CH}_{4}$ of $12.1 \mathrm{yr}$, reaching $56 \%$ of the final response in $10 \mathrm{yr}, 81 \%$ in $20 \mathrm{yr}$, and $92 \%$ in $30 \mathrm{yr}$. Projected changes in emissions of $\mathrm{O}_{3}$ precursors over $30 \mathrm{yr}$ are expected to have only minor effects on the $\mathrm{CH}_{4}-\mathrm{O}_{3}$ sensitivity [West et al., 2006] and on the $\mathrm{CH}_{4}-\mathrm{OH}$ feedback factor [Prather et al., 2001$]$.

[10] The global annual mean radiative forcing is calculated as the instantaneous forcing (long-wave plus short-wave) at the tropopause. We calculate the radiative forcing from $\mathrm{O}_{3}$ using monthly mean $\mathrm{O}_{3}$ fields at steady state and the Geophysical Fluid Dynamics Laboratory radiative transfer model [Freidenreich and Ramaswamy, 1999; Schwarzkopf and Ramaswamy, 1999; Geophysical Fluid Dynamics Laboratory Global Atmospheric Model Development Team, 2004], as employed previously by Naik et al. [2005]. The radiative forcing from $\mathrm{CH}_{4}$ perturbations is estimated at steady state using a simple analytic relationship [Ramaswamy et al., 2001].

\section{Results and Discussion}

\subsection{Changes in Surface $\mathrm{O}_{3}$ Metrics and Net Radiative Forcing}

[11] Figure 1 shows the response of surface ozone $\left(\mathrm{O}_{3}^{\text {srf }}\right)$ to $20 \%$ decreases in anthropogenic precursor emissions. We show the daily maximum 8-hour $\mathrm{O}_{3}$ averaged over the " $\mathrm{O}_{3}$ season," which we define for each grid cell individually as the consecutive three-month period with highest average 8-hr. $\mathrm{O}_{3}$ in the base simulation. The reduction in $\mathrm{O}_{3}^{\text {srf }}$ due to the decrease in $\mathrm{CH}_{4}$ emissions is widespread globally, with the largest effects ( $>1 \mathrm{ppbv})$ in North Africa, the Middle East, and Europe (due to greater down-welling from the free troposphere and availability of $\mathrm{NO}_{x}$ ) in agreement with previous results using different models or meteorology [Fiore et al., 2002; West and Fiore, 2005; West et al., 2006]. In contrast, the responses to changes in $\mathrm{NO}_{x}$, NMVOCs and $\mathrm{CO}$ are concentrated near source regions, 
with changes in background concentrations occurring mainly in the temperate Northern Hemisphere. In some locations (e.g., Northern Russia), $\mathrm{NO}_{x}$ reductions increase the modeled $\mathrm{O}_{3}^{\text {srf }}$ due to the decreased local destruction of $\mathrm{O}_{3}$ by reaction with fresh $\mathrm{NO}$ emissions.

[12] Figure 2 shows the changes in $\mathrm{CH}_{4}$ and $\mathrm{O}_{3}$ concentrations resulting from reductions in emissions of each precursor. The $20 \% \mathrm{CH}_{4}$ reduction yields the greatest decrease in both the tropospheric $\mathrm{O}_{3}$ burden $\left(-6.7 \mathrm{Tg} \mathrm{O}_{3}\right.$; Figure $2 b)$ and the global annual average $\mathrm{O}_{3}^{\text {srf }}(-0.61 \mathrm{ppbv}$; Figure 2c). Our estimated reduction of $0.12 \mathrm{Tg} \mathrm{O}_{3}$ per $\mathrm{Tg} \mathrm{yr}^{-1}$ change in $\mathrm{CH}_{4}$ emissions is within the range of other values in the literature of 0.09 to 0.19 [Prather et al., 2001; Fiore et al., 2002; Shindell et al., 2005; West et al., 2006]. Changes in the $\mathrm{O}_{3}$ burden also compare well for $\mathrm{NO}_{x}(0.29 \mathrm{Tg} \mathrm{O}$ per $\mathrm{Tg} \mathrm{yr}^{-1}$ (as $\mathrm{NO}_{2}$ ), compared to 0.25 to 0.47 from other studies) [Fiore et al., 2002; Shindell et al., 2005; Naik et al., 2005]. Finally, results for the $\mathrm{CO}\left(0.013 \mathrm{Tg} \mathrm{O}_{3}\right.$ per $\left.\mathrm{Tg} \mathrm{yr}^{-1}\right)$ and NMVOC reductions $\left(0.12 \mathrm{Tg} \mathrm{O}_{3}\right.$ per $\left.\mathrm{Tg} \mathrm{C} \mathrm{yr}^{-1}\right)$ agree well with those reported by Fiore et al. [2002] (0.014 and 0.14 , respectively) (see auxiliary material).

[13] Figure 2c also includes changes in $\mathrm{O}_{3}^{\text {srf }}$ metrics relevant for air quality and human health, including the population-weighted daily maximum 8 -hr. $\mathrm{O}_{3}$, averaged over the whole year and over the $\mathrm{O}_{3}$ season. The $20 \%$ $\mathrm{NO}_{x}$ reduction yields the greatest decrease in the population-weighted $\mathrm{O}_{3}^{\text {srf }}$ metrics, as the $\Delta \mathrm{O}_{3}^{\text {srf }}$ is concentrated in populous source regions.

[14] In the United States, $\mathrm{O}_{3}^{\text {srf }}$ responds strongly to the $20 \% \mathrm{NO}_{x}$ reduction, reflecting high regional $\mathrm{NO}_{x}$ emissions and $\mathrm{NO}_{x}$-sensitive chemistry due to the high emissions of biogenic NMVOCs in the eastern US. In Europe, $\mathrm{O}_{3}^{\text {srf }}$ is particularly sensitive to changes in $\mathrm{CH}_{4}$. The NMVOC emission reduction causes rather small changes in $\mathrm{O}_{3}^{\text {srf }}$, in part because of large biogenic NMVOC emissions (the $20 \%$ anthropogenic reduction is only $1.0 \%$ of total NMVOC emissions). Note that the global model likely underestimates the effects of changes in NMVOC emissions on $\mathrm{O}_{3}$ air quality in urban areas, particularly for the populationweighted metrics, due to its coarse resolution and lack of detail for highly reactive VOCs. For $\mathrm{NO}_{x}$ decreases, global models may either under- or overestimate $\mathrm{O}_{3}^{\text {srf }}$ changes in urban regions [Liang and Jacobson, 2000; Karamchandani et al., 2002]. Local sensitivity to changes in emissions of NMVOCs and $\mathrm{NO}_{x}$ is best determined using a local or regional model which has been tested for local conditions.

[15] Figure 2c also shows a notable difference between the short-term and steady-state $\Delta \mathrm{O}_{3}^{\text {srf }}$ metrics, due to longterm changes in $\mathrm{CH}_{4}$. The $20 \% \mathrm{NO}_{x}$ reduction causes longterm increases in the population-weighted $\mathrm{O}_{3}^{\text {srf }}$ metrics of about $0.2 \mathrm{ppbv}$, which counteract the short-term $\mathrm{O}_{3}^{\text {srf }}$ decreases (1.3 to $3.4 \mathrm{ppbv}$ ) by 6 to $14 \%$. For the $\mathrm{CO}$ reduction, the short-term $\Delta \mathrm{O}_{3}^{\text {srf }}(0.4$ to $0.5 \mathrm{ppbv})$ is amplified by about $0.1 \mathrm{ppbv}$ at steady state (a 16-21\% increase). For NMVOCs, the additional long-term $\mathrm{O}_{3}^{\text {srf }}$ decrease is small (about $0.01 \mathrm{ppbv}$ ). These long-term changes in $\mathrm{O}_{3}^{\text {srf }}$ are globally widespread, following the spatial pattern of $\Delta \mathrm{O}_{3}^{\text {srf }}$ from the $\mathrm{CH}_{4}$ perturbation (Figure 1).

[16] Changes in net radiative forcing $\left(\mathrm{RF}_{\text {net }}\right)$ are shown in Figure 2d. The largest negative $\mathrm{RF}_{\text {net }}$ results from the $\mathrm{CH}_{4}$ reduction, with $76 \%$ of the $\Delta \mathrm{RF}_{\text {net }}$ from the decrease in $\mathrm{CH}_{4}$ itself, and the remainder from the decrease in $\mathrm{O}_{3}$.
While reducing each precursor causes a negative forcing due to $\mathrm{O}_{3}$, the $\mathrm{NO}_{x}$ reduction causes a larger positive $\mathrm{CH}_{4}$ forcing, producing a positive global average $\Delta \mathrm{RF}_{\text {net. }}$ This agrees with previous results showing that the $\Delta R F_{\text {net }}$ is positive for surface $\mathrm{NO}_{x}$ emission reductions in all world regions [Fuglestvedt et al., 1999; Berntsen et al., 2005; Naik et al., 2005] (see auxiliary material for a comparison with other $\mathrm{RF}_{\text {net }}$ estimates).

[17] Changes in ozone precursor emissions also affect the concentrations of aerosols, through changes in oxidant chemistry. We find that the $\mathrm{CH}_{4}$ reduction decreases the tropospheric burden of sulfate aerosol by $0.23 \%$, in agreement with previous results [West et al., 2006]. This decrease results from a competition between decreased heterogeneous sulfate production by hydrogen peroxide $\left(-0.9 \mathrm{Tg}_{\mathrm{yr}}^{-1}\right.$, or $\left.-1.1 \%\right)$ and increased gas-phase production by $\mathrm{OH}\left(+0.55 \mathrm{Tg} \mathrm{yr}^{-1}\right.$, or $\left.+2.5 \%\right)$. Decreases in other precursor emissions are likewise estimated to decrease the global sulfate burden: $-0.16 \%$ when decreasing $\mathrm{CO}$, $-0.14 \%$ for NMVOCs, and $-0.06 \%$ for $\mathrm{NO}_{x}$. The global mean positive radiative forcing by the direct effect resulting from each of these decreases in sulfate are estimated to be less than $\sim 0.002 \mathrm{~W} \mathrm{~m}^{-2}$ (see auxiliary material), smaller than the forcings in Figure 2 but potentially important for local forcing [Unger et al., 2006].

\subsection{Change in $\mathbf{R F}_{\text {net }}$ Per Unit Change in $\mathbf{O}_{3}^{\text {srf }}$ Metrics}

[18] We consider the ratio $\Delta \mathrm{RF}_{\text {net }} / \Delta \mathrm{O}_{3}^{\text {srf }}$ as an indicator of the effects on radiative forcing of actions to decrease metrics of $\mathrm{O}_{3}$ air quality by a given amount. High positive values indicate that actions to reduce $\mathrm{O}_{3}^{\text {srf }}$ by one unit cause a large negative radiative forcing. In Figure 2e, the $\mathrm{CH}_{4}$ emission reduction causes the largest decrease in $\mathrm{RF}_{\text {net }}$ per unit $\Delta \mathrm{O}_{3}^{\text {srf }}$, mainly due to the decreased forcing from $\mathrm{CH}_{4}$ itself. Reductions in $\mathrm{NO}_{x}$ increase $\mathrm{RF}_{\text {net }}$, causing a negative $\Delta \mathrm{RF}_{\text {net }} / \Delta \mathrm{O}_{3}^{\mathrm{srf}}$. Abatement of $\mathrm{CO}$ emissions leads to a greater $\Delta \mathrm{RF}_{\text {net }} / \Delta \mathrm{O}_{3}^{\text {srf }}$ than for NMVOCs, as the ratio of the reduction in $\mathrm{CH}_{4}$ to $\mathrm{O}_{3}$ is greater for $\mathrm{CO}$. We find that the order of $\Delta \mathrm{RF}_{\text {net }} / \Delta \mathrm{O}_{3}^{\text {srf }}\left(\mathrm{CH}_{4}, \mathrm{CO}, \mathrm{NMVOCs}, \mathrm{NO}_{x}\right)$ is the same for all $\Delta \mathrm{O}_{3}^{\text {srf }}$ metrics considered, and we expect this order to be robust over model uncertainties as well. If $\Delta \mathrm{RF}_{\text {net }}$ were evaluated after a short time period $(<10 \mathrm{yr})$, however, the change in short-term $\mathrm{O}_{3}$ forcing would dominate, and the order of the precursors would likely differ.

\section{Conclusions}

[19] We first consider the sensitivity of surface $\mathrm{O}_{3}$ air quality and net radiative climate forcing to reductions in global $\mathrm{O}_{3}$ precursor emissions. For $\mathrm{O}_{3}$ air quality, the $20 \%$ reduction in anthropogenic $\mathrm{NO}_{x}$ emissions has the greatest effect on the population-weighted $\mathrm{O}_{3}^{\text {srf }}$ metrics analyzed, followed by $\mathrm{CH}_{4}$, although the long lifetime of $\mathrm{CH}_{4}$ delays realization of the $\mathrm{O}_{3}$ decrease. The $\mathrm{CH}_{4}$ reduction causes the greatest decrease in $\mathrm{RF}_{\text {net }}$, mainly because of the direct reduction in $\mathrm{CH}_{4}$ forcing, while $\mathrm{NO}_{x}$ emission reductions increase $\mathrm{RF}_{\text {net }}$. Second, we present an indicator of the climate forcing resulting from actions to improve $\mathrm{O}_{3}$ air quality $\left(\Delta \mathrm{RF}_{\text {net }} / \Delta \mathrm{O}_{3}^{\text {srf }}\right)$. We find that of the means of decreasing $\mathrm{O}_{3}^{\text {srf }}$ metrics by one unit, abatement of $\mathrm{CH}_{4}$ emissions best reduces radiative forcing. 
[20] This research also demonstrates that the long-term changes in surface $\mathrm{O}_{3}$ concentrations via changes in $\mathrm{CH}_{4}$ are substantial for $\mathrm{NO}_{x}$ and $\mathrm{CO}$ reductions, and relevant for air quality management. While the $20 \%$ anthropogenic $\mathrm{NO}_{x}$ emission reduction decreases short-term $\mathrm{O}_{3}^{\text {srf }}$, it also causes a long-term global increase of about $0.2 \mathrm{ppbv}$ in populationweighted $\mathrm{O}_{3}^{\text {srf }}$ metrics, which counteracts the short-term decrease by 6 to $14 \%$. For $\mathrm{CO}$, the long-term $\mathrm{O}_{3}^{\text {srf }}$ reduction of $0.1 \mathrm{ppbv}$ adds 16 to $21 \%$ to the short-term decrease, while the long-term $\mathrm{O}_{3}^{\text {srf }}$ reduction of the $20 \%$ NMVOC reduction is small $(0.01 \mathrm{ppbv})$.

[21] We also find that reducing emissions of each precursor decreases the global sulfate aerosol burden $(<0.3 \%$ for the $20 \%$ anthropogenic reductions). Future research should further address the effects of these emission changes on all relevant aerosol species (including secondary organics), and evaluate impacts on both surface air quality and global and regional aerosol radiative forcing. Further, while the methods presented here are convenient for considering short-term and steady-state changes, future research should conduct transient simulations with $\mathrm{CH}_{4}$ modeled explicitly, to explore possible interactions between reductions in different species under future scenarios [Dentener et al., 2005].

[22] In addition to the traditional focus of $\mathrm{O}_{3}$ air quality management on local and regional scales, changes in precursor emissions also cause long-term changes in $\mathrm{O}_{3}^{\text {srf }}$ and radiative climate forcing on a global scale. Although the long-term effects of actions to manage $\mathrm{O}_{3}^{\text {srf }}$ in a single airshed are expected to be small, the cumulative effects of such actions globally are significant. Because of these longterm air quality and climate effects, therefore, it may be desirable to emphasize $\mathrm{CH}_{4}$ abatement, and to increase the emphasis of $\mathrm{O}_{3}$ air quality control on $\mathrm{CO}$ and NMVOC abatement. While the $\Delta R F_{\text {net }} / \Delta \mathrm{O}_{3}^{\text {srf }}$ indicators presented here are useful in considering the climate effects of actions to improve air quality, we would ideally like to know the least-cost combination of emission reduction measures that would jointly achieve air quality and climate objectives [West et al., 2004], and future work should combine our results with relevant control costs. In the case of $\mathrm{CH}_{4}$, a large potential for low-cost and cost-saving emission controls has been identified, mainly in industrial sectors [West and Fiore, 2005].

[23] Acknowledgments. We thank H. Levy, P. Ginoux, and anonymous reviewers. This work was supported by the National Oceanic and Atmospheric Administration, and a National Aeronautics and Space Administration New Investigator Program grant to D.L.M.

\section{References}

Berntsen, T. K., et al. (2005), Response of climate to regional emissions of ozone precursors: Sensitivities and warming potentials, Tellus, Ser. B, 57, $283-304$.

Dentener, F., et al. (2005), The impact of air pollutant and methane emission controls on tropospheric ozone and radiative forcing: CTM calculations for the period 1990-2030, Atmos. Chem. Phys., 5, $1731-1755$

Fiore, A. M., D. J. Jacob, B. D. Field, D. G. Streets, S. D. Fernandes, and C. Jang (2002), Linking ozone pollution and climate change: The case for controlling methane, Geophys. Res. Lett., 29(19), 1919, doi:10.1029/ 2002GL015601

Freidenreich, S. M., and V. Ramaswamy (1999), A new multiple-band solar radiative parameterization for general circulation models, J. Geophys. Res., 104, 31,389-31,409.

Fuglestvedt, J. S., et al. (1999), Climatic forcing of nitrogen oxides through changes in tropospheric ozone and methane; global 3D model studies, Atmos. Environ., 33, 961-977.

Geophysical Fluid Dynamics Laboratory Global Atmospheric Model Development Team (2004), The new GFDL global atmosphere and land model AM2-LM2: Evaluation with prescribed SST simulations, J. Clim., $17,4641-4673$

Horowitz, L. W., et al. (2003), A global simulation of tropospheric ozone and related tracers: Description and evaluation of MOZART, version 2, J. Geophys. Res., 108(D24), 4784, doi:10.1029/2002JD002853.

Karamchandani, P., C. Seigneur, K. Vijayaraghavan, and S.-Y. Wu (2002), Development and application of a state-of-the-science plume-in-grid model, J. Geophys. Res., 107(D19), 4403, doi:10.1029/2002JD002123.

Liang, J. Y., and M. Z. Jacobson (2000), Effects of subgrid segregation on ozone production efficiency in a chemical model, Atmos. Environ., 34, $2975-2982$

Naik, V., D. Mauzerall, L. Horowitz, M. D. Schwarzkopf, V. Ramaswamy, and M. Oppenheimer (2005), Net radiative forcing due to changes in regional emissions of tropospheric ozone precursors, J. Geophys. Res., 110, D24306, doi:10.1029/2005JD005908.

Prather, M. J. (1996), Time scales in atmospheric chemistry: Theory, GWPs for $\mathrm{CH}_{4}$ and $\mathrm{CO}$, and runaway growth, Geophys. Res. Lett., 23, 25972600.

Prather, M., et al. (2001), Atmospheric chemistry and greenhouse gases, in Climate Change 2001: The Scientific Basis, edited by J. T. Houghton et al., pp. 239-287, Cambridge Univ. Press, New York.

Ramaswamy, V., et al. (2001), Radiative forcing of climate change, in Climate Change 2001: The Scientific Basis, edited by J. T. Houghton et al., pp. 349-416, Cambridge Univ. Press, New York.

Schwarzkopf, M. D., and V. Ramaswamy (1999), Radiative effects of $\mathrm{CH}_{4}$, $\mathrm{N}_{2} \mathrm{O}$, halocarbons, and the foreign-broadened $\mathrm{H}_{2} \mathrm{O}$ continuum: A GCM experiment, J. Geophys. Res., 104, 9467-9488.

Shindell, D. T., G. Faluvegi, N. Bell, and G. A. Schmidt (2005), An emissionsbased view of climate forcing by methane and tropospheric ozone, Geophys. Res. Lett., 32, L04803, doi:10.1029/2004GL021900.

Unger, N., D. Shindell, D. M. Koch, and D. G. Streets (2006), Cross influences of ozone and sulfate precursor emissions changes on air quality and climate, Proc. Natl. Acad. Sci. U. S. A., 103, 4377-4380.

Vingarzan, R. (2004), A review of surface ozone background levels and trends, Atmos. Environ., 38, 3431-3442.

West, J. J., and A. M. Fiore (2005), Management of tropospheric ozone by reducing methane emissions, Environ. Sci. Technol., 39, 4685-4691.

West, J. J., et al. (2004), Co-control of urban air pollutants and greenhouse gases in Mexico City, Environ. Sci. Technol., 38, 3474-3481.

West, J. J., A. M. Fiore, L. W. Horowitz, and D. L. Mauzerall (2006), Global health benefits of mitigating ozone pollution with methane emission controls, Proc. Natl. Acad. Sci. U. S. A., 103, 3988-3993.

Wild, O., M. J. Prather, and H. Akimoto (2001), Indirect long-term global radiative cooling from $\mathrm{NO}_{\mathrm{x}}$ emissions, Geophys. Res. Lett., 28, 17191722 .

A. M. Fiore, L. W. Horowitz, and M. D. Schwarzkopf, NOAA Geophysical Fluid Dynamics Laboratory, 201 Forrestal Road, P.O. Box 308, Princeton, NJ 08542-0308, USA.

D. L. Mauzerall and V. Naik, Woodrow Wilson School of Public and International Affairs, Princeton University, Robertson Hall, Princeton, NJ 08544, USA.

J. J. West, Department of Environmental Sciences and Engineering, University of North Carolina, Chapel Hill, NC 27599, USA. (jwest@ princeton.edu) 